\title{
THE GENESIS OF THE BASE METAL ORE DEPOSIT FROM HERJA
}

\section{GHEORGHE DAMIAN $^{1}$}

\begin{abstract}
The Herja ore deposit is one of the most known of the Baia Mare Neogene metallogenetic district and is associated with a complex stock of Pannonian age. The hydrothermal alterations associated with the mineralizations are represented by: the propylitization, the argillization, the phyllic and potassic alteration. The monoascenedant character of the mineralizations is predominant. The magmatic intrusions have been sequential placed and have represented the heat, metals and hydrothermal solutions source. In the first stages of mineralization the hydrothermal solutions contain predominantly magmatic water and in the final stages the water is of connate and meteoric origin. According to the structural magmatic control, to the mineralogical composition and to the hydrothermal alterations, the Herja ore deposits are of a low sulphidation epithermal systems type.
\end{abstract}

Keywords: Magmatic intrusions, Alteration, Depositional environment, Monoascendant, Source, Model, Epithermal.

\section{INTRODUCTION}

Baia Mare area is known for its hydrothermal ore deposits where the Herja ore deposit is also situated (Fig. 1). Petrulian (1934) carried out the first study. According to Ghițulescu (1935) the upper levels of the veins had a mineralization rich in silver and stibium. The most comprehensive image regarding the volcanic and metallogenetical evolution of the Herja area was made by Borcoş et al. (1973) and Giuşcă et al. (1973). They affirm that the development of Herja ore deposit belongs to the third metallogenetical phase, the last one in the Baia Mare area.

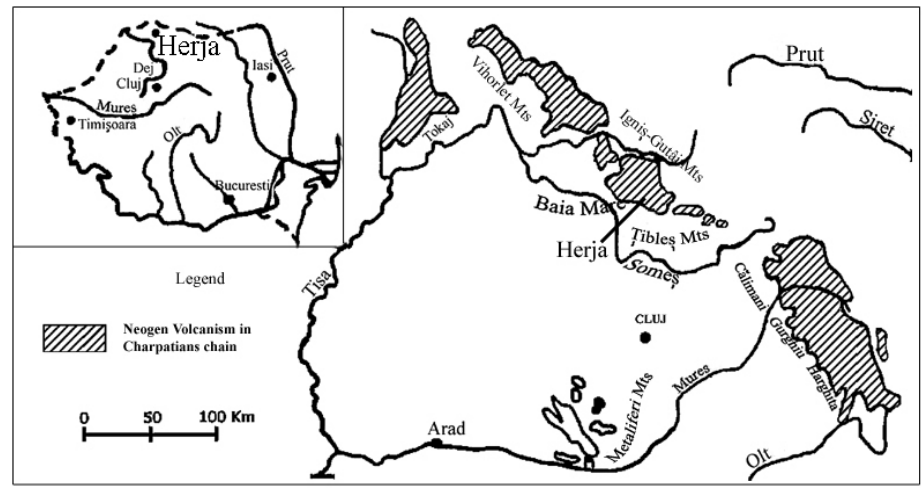

Fig. 1. Location of Herja ore deposit in the East Carpathians neogene volcanic area, after Borcoş \& Vlad (1994).

\footnotetext{
${ }^{1}$ North University of Baia Mare, 4800 Baia Mare, V. Babeş Street, 62/A; e-mail: damgeo@ubm.ro
} 


\section{THE GEOLOGY AND PETROGRAPHY OF THE AREA}

In the Herja zone are known sedimentary tertiary and Neogene magmatic formations. The sedimentary formations belong to the Eocene, Sarmatian and Pannonian (Marinescu in Borcoş et al., 1973). The neogene magmatites are represented by volcanic products and by intrusive bodies. The volcanic products are represented by lava flows and subordinately, pyroclastic rocks. The vulcanites are represented by pyroxene and quartz andesites.

The hydrothermalized pyroxene andesites appear at Piciorul Herjei, Herja river and Jidovia river and were crossed by loachim lower gallery $(+380 \mathrm{~m})$. Initially these andesites were considered equivalent to the Seini andesite of Sarmatian age (lanovici et al., 1961), and P. Polonic and G. Polonic (1962) consider them Jereapăn andesites (Pontian). Later, Iştvan et al. (1986) considered them to be of Pannonian age because they are covered by Piscuiatu Pannonian quartz andesites. The K-Ar radiometric determinations (Edelstein et. al., 1992) confirmed the lower Pannonian age of these andesites. The Piscuiatu quartz andesites are situated in the southern part of the area, disposed directly over the Pannonian formations.

On the south ridge of Cuților Valley pyroxene andesites were identified. Based on the stratigraphic sequence they were considered to be of Pontian age and equivalent to the Jereapăn andesites, which were inserted in the second cycle of eruption, within the third phase (Giuşcă et al., 1973).

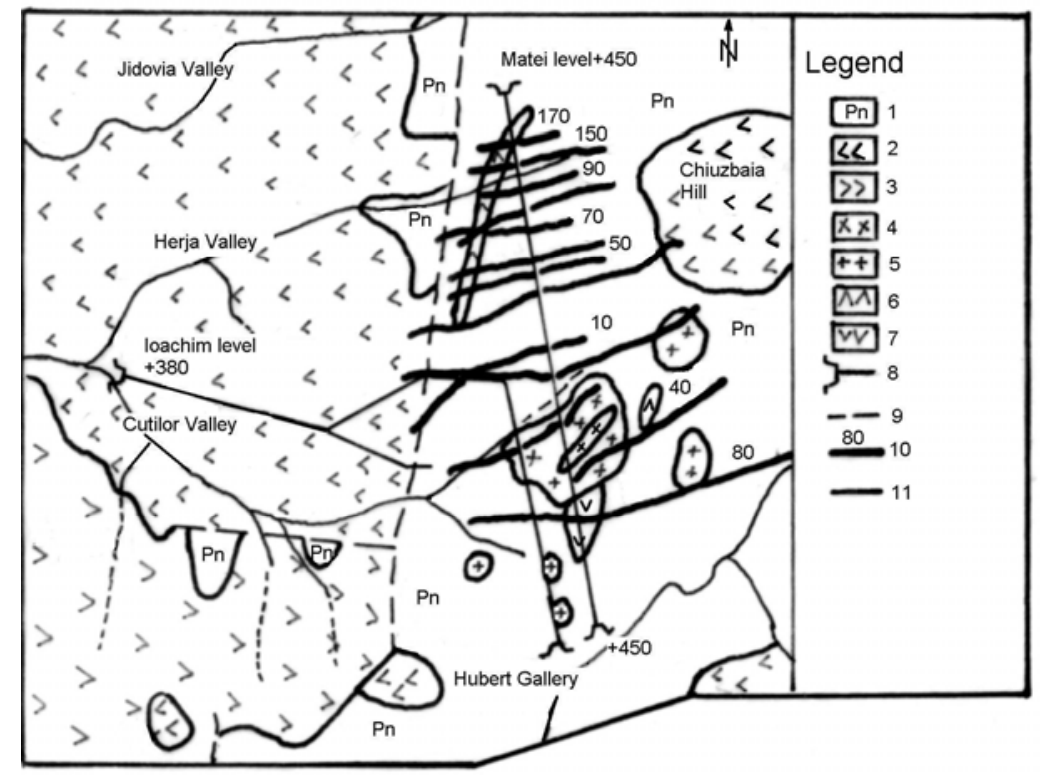

Fig. 2. Geological map of the Herja zone: 1 - Pannonian; 2- pyroxene andesites; 3 - quartz andesites; 4 - porphyry microtonalites; 5 - porphyry quartz - microdiorites; 6 - pyroxene andesites; 7 - quartz andesites; 8 - gallery; 9 - fault; 10 - vein; 11 - geological limit. 
Borcoş (in Borcoş \& Vlad, 1994) and Borcoş et al. (1998), suggests the presence of a pluton on the southern border of the Baia Mare area. We are considered that the intrusions discovered up to this moment represent the peaks of some subvolcanic intrusions of greater dimensions, having a dioritic and monzodioritic composition similar to the ones noticed at Herja by Jude (1960).

The bodies of intrusive magmatic rocks appear as dykes and stocks. The first intrusive bodies are the dykes (NE - SW), made of quartz andesites in the southern part and pyroxene andesites in the northern and eastern part of the mine (Fig. 2, 3). Enclaves like these have been found in the central part of the stock, which contains porphyry quartz-microdiorites (Fig. 3, 4). The dykes from the northern part are made of strongly hydrothermalized andesites. The other two dykes situated in the north - eastern part are made of sericitized andesites.

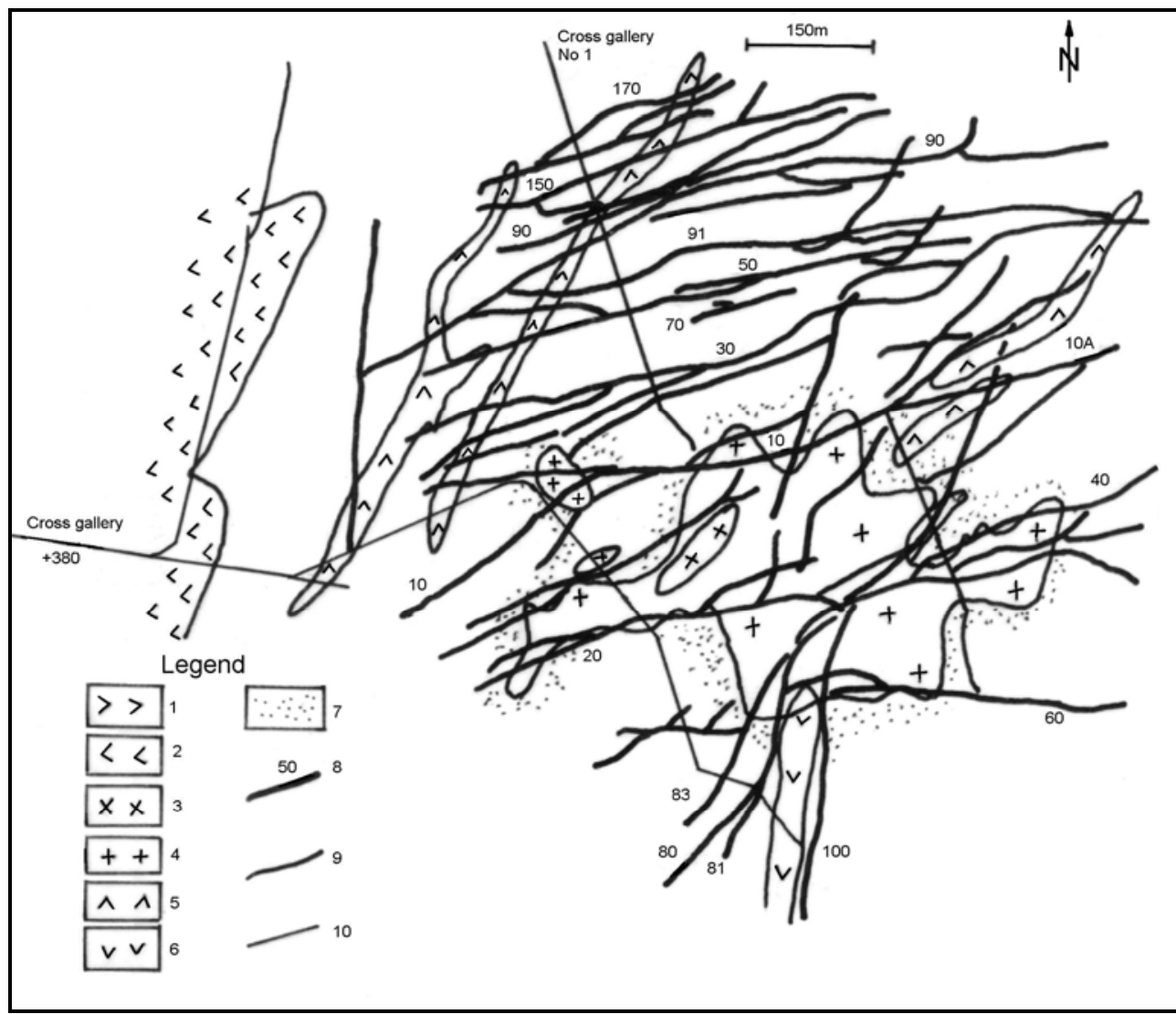

Fig. 3. Geological map of level +380: 1 - Pannonian; 2 - pyroxene andesites; 3 - porphyry microtonalites; 4 - porphyry quartz - microdiorites; 5 - pyroxene andesites; 6 - quartz andesites; 7 - hornfels; 8 - vein; 9 -geological limit; 10 - gallery; 11 - position. 
The main body is constituted of porphyry quartz-microdiorites, which marginally, and towards the upper part have an andesitic character. This body is a stock with irregular margins in the horizontal and vertical plan (Fig. 3). The microdiorites have been intercepted in only one apophyse in the central part of Herja ore deposit (Fig. 4). Between Şălan vein and Zincos vein, a dyke of porphyry microtonalites was found (Fig. 4). At lower levels, the main intrusion of porphyry quartz microdiorites is pierced by small dykes by porphyry microdiorites and by porphyry micromonzodiorites (Fig. 4). The relations between the main intrusive magmatic rocks emphasize their sequential formation.

Products of the thermic contact metamorphism were identified as being connected to the main intrusions from the investigated area. In areas influenced by the intrusive bodies, various types of hornfelses were identified, which reflect a change in intensity of the recrystallisation processes depending on the nature of the petrotype and the distance to the contact with the magmatic rocks.

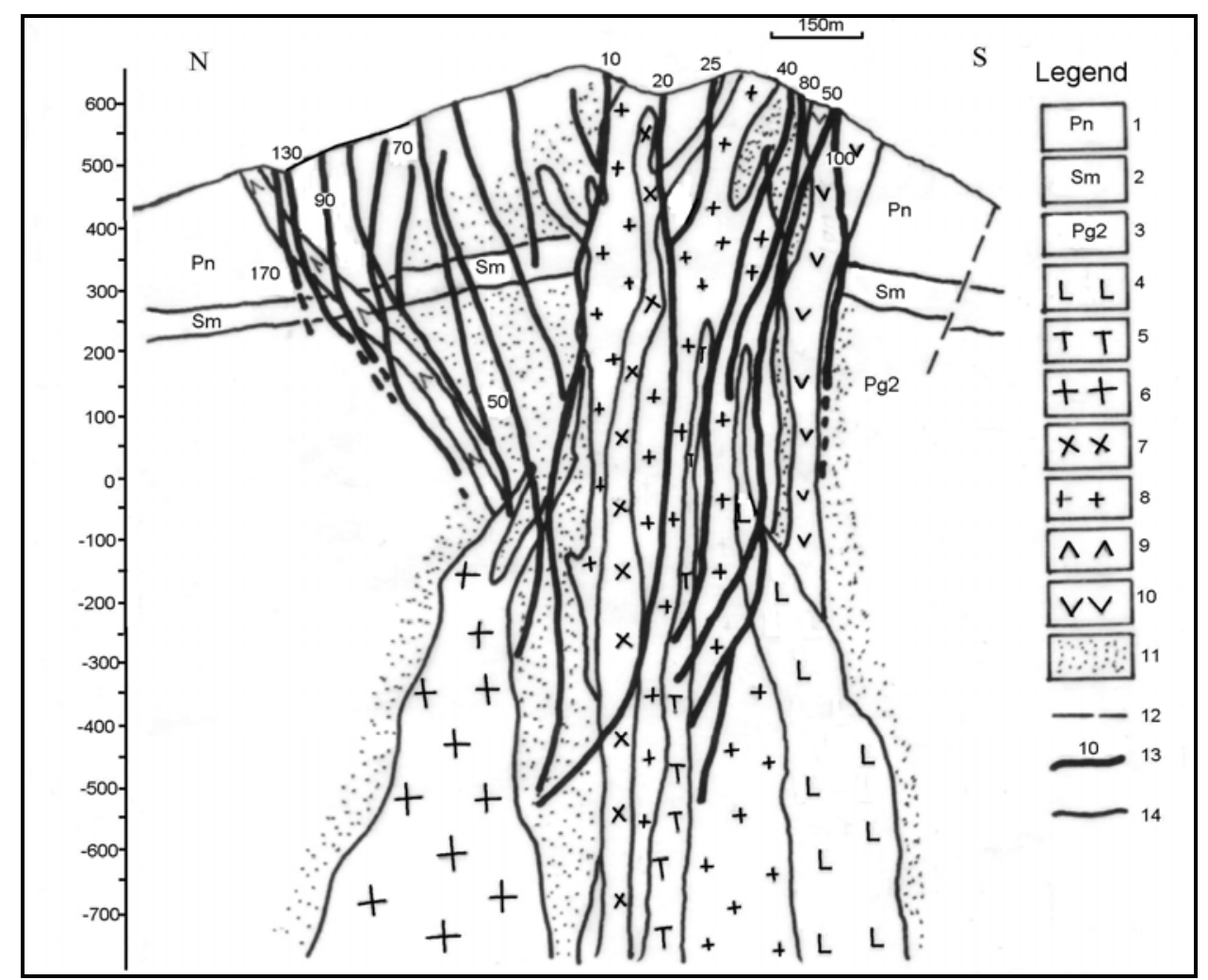

Fig. 4. Geological section through Herja ore deposit: 1 - Pannonian; 2 - Sarmatian; 3- Eocene; 4 - porphyry quartz-Micromonzonites; 5 - porphyry microdiorites; 6 - microdiorites; 7 - porphyry microtonalites; 8 - porphyry quartz - microdiorites; 9 - pyroxene andesites; 10 - quartz andesites; 11 - hornfelses 12 - fault; 13 - vein; 14 - geological limit. 
The magmatic rocks, and sporadically the sedimentary ones are differently affected by the hydrothermal fluids. The most significant hydrothermal alterations are: the propilitic, the argillization, the phyllic and potassic. The andesitic dykes formed in the first stages are most affected by hydrothermal alterations. The intrusive magmatic rocks, inserted during the final stages of the magmatic processes are only propylitizated. Observations carried out within the limits of mining works and drillings emphasized a weak tendency of vertical zonality of the hydrothermal alterations, only within the main body of porphyry quartz-microdiorites. At the lower levels, around the Clementina (60) vein, the adularization is dominant, being accompanied by silicification and sericitization towards the exterior. The adularization was also signalled by Stanciu (1973) around vein Ignațiu (40). The northern and western extremity of the porphyry quartz-microdiorites body and some of the adjacent apophyses is mainly sericitized, while the southern and eastern area is intensely sericitized and argillized. The hydrothermal alterations offer an image about the character of the solutions, which brought their contribution to the changing of the initial mineralogical composition.

\section{THE TYPE OF PRESENTATION AND DISTRIBUTION OF THE MINERALIZATIONS}

The metallogenesis associated to the Neogene magmatism from the Herja area generated important concentrations of $\mathrm{Pb}, \mathrm{Zn}, \mathrm{Ag}$ and subordinately $\mathrm{Au}, \mathrm{Cu}, \mathrm{Sb}$. The vein area Herja has a surface of approximately $1 \mathrm{~km}^{2}$ and over 260 known veins. The veins are disposed in fractures, with E-W or ENE-WSW orientations, and subordinately NNE-SSW (Fig. 3). These fractures constituted the access ways for the hydrothermal solutions, which generated well individualized veins, sometimes with variable thickness in direction and pitch. This way a vein system resulted, which has the aspect of a network with quasi-parallel disposed veins.

The first complex of veins would be the diagonal one with the direction NNE-SSW, localized in the southern part of the field. The main complex of fractures has the orientation ENE-WSW and is represented by the following veins: Şălan (10), Ignațiu (40), Clementina (60), 30, 50, 70, 90, 110, 130, 150, 170 and their branches. The final complex of diagonal fractures has the direction N-S and includes vein branches situated in the northern part of the ore deposit. The main vein of the Herja ore deposits is Şălan (10) situated in the central area, near the northern contact of the porphyry quartz-microdiorites stock (Fig. 3). Reported to the vein two groups of veins can be separated, the northern and the southern group. The northern group of veins, is mainly localized in sedimentary formations and pitches towards the vein Şălan (10). The southern group is mainly localized in intrusive bodies. The veins from the northern group have a reduced development in pitching and below level (-IV) they are low mineralized. The vein branches have reduced dimensions in direction and pitch. They are localized either near the main veins, or at some distances away from these. 


\section{ORE TEXTURE AND STRUCTURE}

The mineralizations are characterized by the following types of textures: massive, banded, brecious, impregnation and geodes. The massive texture indicates that the mineralizing solutions have been very concentrated. The banded texture is not very frequent in the Herja ore deposit. The banded textures reflect a slow deposition in only one stage of the mineralization process. The subordinate presence of the banded textures and the predominant massive textures indicate a monoascendent process of mineralization during which we can clearly delimit a simple mineralogenetic sequence.

The brecious and impregnated textures appear very rarely. The geodes are frequent enough and they can sometimes reach metrical dimensions. Frequently, the geodes are upholstered with sphalerite, galena, chalcopyrite and stibnite crystals. The sphalerite and galena crystals from the geodes can reach sizes of up to $7-8 \mathrm{~cm}$.

The main types of identified structures are: exsolution, substitution and grain structures. The grain structures belong entirely to the holocrystal type. Sphalerite and galena crystals frequently appear, sometimes with centimeter sizes. The chalcopyrite and tetrahedrite crystals are also frequent. The exsolution structures are frequent between chalcopyrite and sphalerite. Seldom do cubanite micronic inclusions appear in chalcopyrite and more often pyrrhotite micronic inclusions appear in sphalerite.

\section{MINERALOGICAL COMPOSITION}

The mineralization in the veins from Herja ore deposit has a complex mineralogical composition, the main minerals being represented by common sulphides: pyrite, pyrrhotite, sphalerite, galena, to which we can add some sulphosalts, like carbonates, sulphates, silicates, forming a real natural mineralogical museum (Fig. 5). The Herja ore deposit represents classical occurrences for many rare minerals: fizelyte, semseyite, stibnite, tetrahedrite, jamesonite, freislebenite to which we can add recent discovered minerals: freibergite, diaforite, fülöppite, plagionite, andorite, calcostibite, heteromorphite, zinkenite, bournonite, jordanite, proustitepirargirite, polibazite, native gold, ilvaite (Damian, 1996; Cook \& Damian, 1997).

Pyrrhotite is frequently found in the mineralizations from Herja and is represented both by monoclinic and hexagonal types. The sphalerite is characterized by high contents in iron (14-16\% mol FeS). Many of the tetrahedrites correspond to the freibergite and argentian tetrahedrites. The vivianite is situated on pyrrhotite crystals, and the ilvaite was also identified.

\section{THE GENESIS OF THE MINERALIZATION}

The debates regarding the genesis of the mineralization involve many aspects like the structural control, the origin and evolution of the magma, the source of the elements, the deposition sequence of the mineral components, forming temperature and pressure, transport and precipitation conditions, water sources, the variation of the hydrothermal solutions composition and the manner of deposition for the elements in the solution. 


\section{The magmatic seguences}

The Baia Mare area represents a fragment from a magmatic arc belonging to the Eastern Carpathians, where the African plate meets the European plate (Balintoni, 1997). The subduction process took place from west to east, through the subduction of the oceanic crust from the Eastern Carphatians basin under the extern Dacides (Rădulescu \& Săndulescu, 1973). During the subduction process, the oceanic crust and sediments begin to dehydrate with the result of fluids rich in water, or a silicate melt, strongly hydrated and enriched in LIL and LREE elements. The fluids inserted in the mantle above the subdued plate lower the melting point and initiate its partial melting. The magma formed in such conditions is rich in fluids, begins to rise and accumulates in magmatic chambers.

The magma standing at the origin of the magmatic rocks from the Herja area is of andesitic type with a high content in potassium and a calc-alkaline and metaluminous character. The $\mathrm{Rb} / \mathrm{Sr}$ ratio of 0.304 for the magmatic rocks from the Herja area, as well as the ${ }^{87} \mathrm{Sr} /{ }^{86} \mathrm{Sr}$ ratio of 0.7081 (Kovacs et al., 1992), indicates a reduced crust contamination.

The magmas migrated upward, into intermediary magmatic chambers, which correspond to the pluton signalled by Borcoş \& Vlad (1994). From these chambers, by a not so advanced separation process, magmas were formed, which were intermittently pulsed and from which the actual intrusive structure from Herja area resulted. In the first stage, effusive-volcanic structures were formed, mostly destroyed afterwards by erosion (Măldărăscu, 1977).

The intrusive rocks bodies represent a later sequence if we are to report to the main lava flows. The intrusive magmatic rocks are sequential placed, in a few distinct stages. A complex intrusive structure resulted, made out of a composed stock. In a first stage the andesitic dykes were formed, having the NE-SW orientation, followed by the intrusion of the main body and the satellite porphyry quartz-microdiorite bodies. Later, the main body was pierced by small apophyses of microtonalites porphyry, microdiorites, porphyry microdiorites and porphyry quartz-micromonzodiorites.

\section{Temperature and pressure of the mineral paragenesis}

The composition of some mixed crystals can be used to determine the formation temperature. The geothermometer based on the FeS-ZnS system was invalidated by the research carried out by Barton \& Toulmin (1966) and Boorman (1967). At temperatures of great metallogenetic interest, $300^{\circ}-600^{\circ} \mathrm{C}$, the $\mathrm{FeS}$ content of the sphalerite depends on the pressure. This way, the use of sphalerite as a geobarometer is possible, for the entire area of variation of the FeS content. Scott \& Barnes (1971), Scott (1973) discuss the possibility of using sphalerite as a geobarometer. More complex data regarding the dependence at the FeS content from sphalerite on ppressure results from the experiences carried out by Hutchinson \& Scott (1981). Using the composition data of the sphalerite associated with pyrrhotite and pyrite we can obtain a pressure between 500 bars and 1,5kb (Damian, 1996). The pressure data obtained based on the sphalerite composition are according to Udubaşa et al. (1985) for some subvolcanic ore deposits from Romania. 
The more exact determination of the temperature for the pyrite-sphaleritepyrrhotite association can be done with the solvus curve drawn up by Arnold (1962), based on the iron content in pyrrhotite. The iron content in pyrrhotite is $46.9-47.1 \% \mathrm{Fe}$ with a corresponding temperature of $350-400^{\circ} \mathrm{C}$ (Damian, 1996).

The isotopic composition of the sulphur was used for the estimation of the forming temperature of the mineral association. The sulphides couple used to determine the formation temperature is pyrite-galena, based on the relation of Ohmato \& Rye (1979). The temperature is between $320^{\circ} \pm 70^{\circ} \mathrm{C}$ and $417^{\circ} \pm 75^{\circ} \mathrm{C}$. By correlating these temperatures with the ones obtained for other associations of pyrite we can state that the first generations deposited at temperatures of $350^{\circ} \mathrm{C}$.

The results of some determinations regarding the deposition temperature obtained based on the homogenization of the biphasic inclusions in the minerals from Herja were presented by Pomârleanu (1971) and Manilici \& Dumitrescu (1981). The temperature limits obtained for the entire Herja ore deposit through the homogenization of the quartz biphasic inclusions, are between $194^{\circ}-285^{\circ} \mathrm{C}$. Pomârleanu also admits a general growth of temperature for quartz, that begins from the surface towards the lower levels. The homogenization temperature obtained on biphasic inclusions from fluorine is between $220^{\circ}-225^{\circ} \mathrm{C}$ and from calcite is between $190^{\circ}-200^{\circ} \mathrm{C}$.

The results obtained through the homogenization of the biphasic inclusions are between $202^{\circ}-294^{\circ} \mathrm{C}$, with medium temperature values between $240^{\circ}-277^{\circ} \mathrm{C}$. A temperature rise can be noticed, from level $+250 \mathrm{~m}$ to level $+180 \mathrm{~m}$. The obtained data have higher values than the ones presented by Pomârleanu (1971). The conclusion is that, for the entire Herja ore deposit, the temperature obtained through the homogenization of the quartz biphasic inclusions rises gradually from the higher levels $\left(215^{\circ}-220^{\circ} \mathrm{C}\right)$ towards the lower levels $\left(277^{\circ}-282^{\circ} \mathrm{C}\right)$.

\section{The deposition sequence of the minerals}

Based on the entire composition of the mineralization, on the structure, texture and the mutual relationships between the minerals, we consider that the deposition process of the minerals had a predominantly monoascendant character (Fig. 5).

The mineralization process started at a high temperature, beginning with the deposition of the ilvaite associated with epidote, pyrite and quartz. It is followed by the massive deposition of pyrite, moment in which the solutions were rich in iron and sulphur. The small quantities of copper and zinc form, in the presence of iron, sphalerite with chalcopyrite exsolutions. After the exhaustion of zinc and the relative growth of the copper content, chalcopyrite begins to precipitate as sphalerite star exsolutions. The As ions that are present in the solution combine with iron and sulphur forming arsenopyrite and loellingite.

As the sulphur exhausts, the conditions become favorable to the development of pyrrhotite. The greatest quantity of sphalerite appears associated with pyrrhotite. The high content of FeS from sphalerite, the composition of pyrrhotite and sulfur isotopes indicate their formation at temperatures of over $300^{\circ} \mathrm{C}$. The 
high content of FeS from the solutions is maintained afterwards because the sphalerite retains great quantities of iron and a lot of submicroscopic pyrrhotite inclusions. The copper dissolved in the solid solution of Fe-Zn-Cu-S separates from the rest, taking the form of grains and small veins associated with sphalerite. The salinity of the solutions is high at these moments, with a neutral or slightly acid $\mathrm{pH}$, because these are capable to increase considerably the solubility of the metals. The moment of deposition for pyrrhotite and sphalerite are characterized by a great FeS activity in the sphalerite structure.

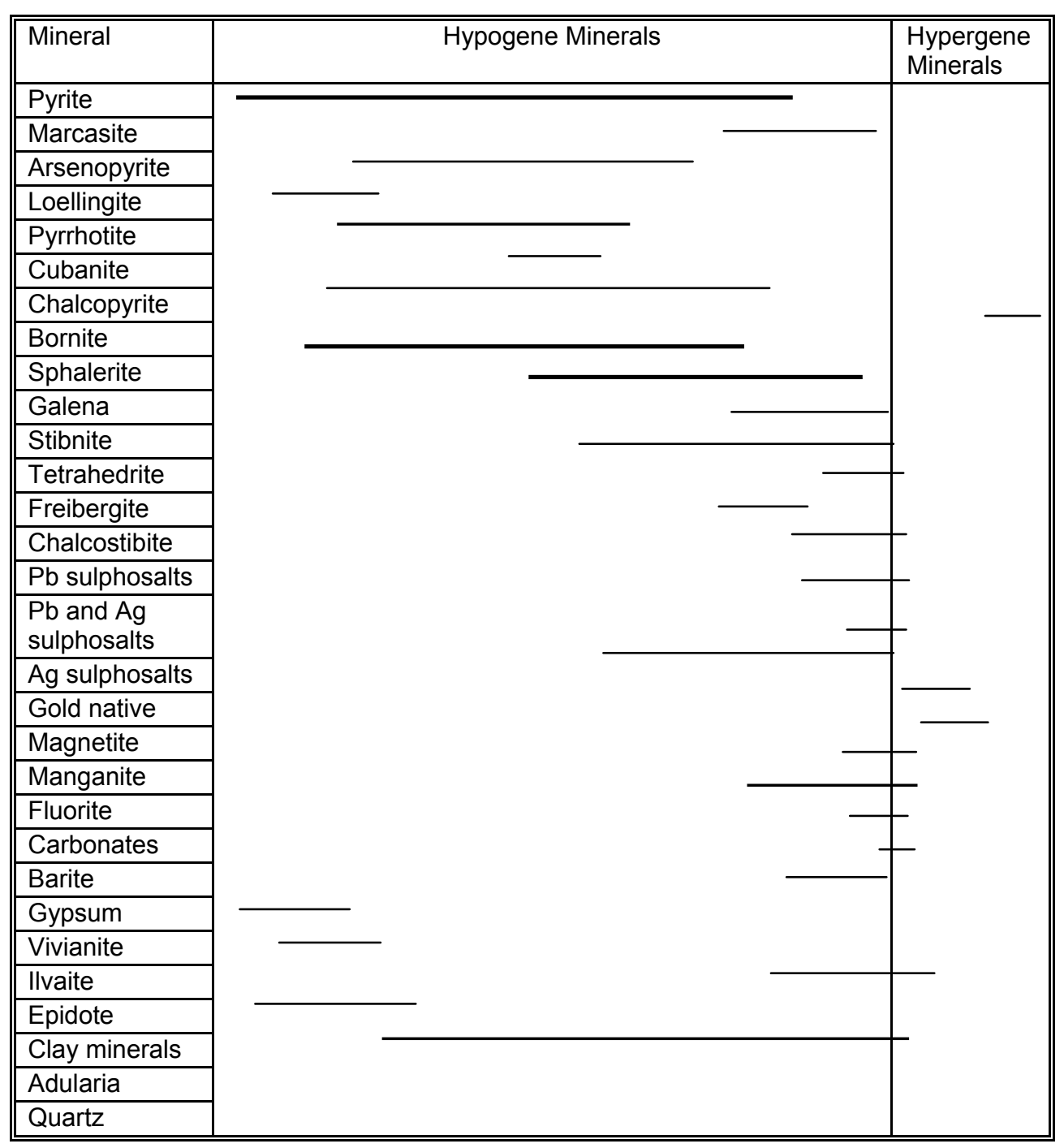

Fig. 5. The deposition sequence of the mineral components. 
The As left in the solution favorites the deposition of arsenopyrite as small inclusions in sphalerite and chalcopyrite. Concomitant with the rising of As content the rise of $\mathrm{Sb}$ content, can be noticed too, that can settle in the tetrahedrite's crystalline structure. This is followed by the deposition of a small quantity of native gold included in the sphalerite and in the pyrite.

Gradually, the temperature decreases below $300^{\circ} \mathrm{C}$, correlated with the growth of the led, silver and stibium content from the hydrothermal solutions. As the temperature lowers, the pressure is also reduced because the galena from the high salinity solutions precipitates in great quantities. Together with the galena, small quantities of pyrite, sphalerite and chalcopyrite are also deposed. In the upper parts of the veins, appreciable quantities of native gold are included in galena. The remains of $\mathrm{Fe}, \mathrm{Cu}, \mathrm{Zn}$, together with $\mathrm{Sb}, \mathrm{Ag}$ and As from the hydrothermal solutions form the freibergite. Towards the end of the crystallization of galena, the content in $\mathrm{Sb}$ of the solutions is high enough to favour the deposition of stibnite at a temperature of $250^{\circ}-280^{\circ} \mathrm{C}$. Later the solutions have a lower salinity and become richer in $\mathrm{Fe}$ and $\mathrm{S}$, moment when the marcasite, berthierite and jamesonite are precipitated. The rest of $\mathrm{Cu}$ from solution favours the formation of bournonite at low pressures and temperatures close to the ones characterizing the quartz in geodes $\left(220^{\circ}-270^{\circ} \mathrm{C}\right)$. This is followed by the massive crystallization of the sulphosalts from the group plagionite, zinkenite, and jordanite, followed by silver and led sulphosalts. Concomitant with the crystallization of the sulphosalts, the precipitation of quartz takes place in geodes from solutions with low salinity and high $\mathrm{O}_{2}$ fugacities.

Carbonates depose from the final solutions, correlated with the growth of $\mathrm{CO}_{2}$ and in the presence of oxygen. From these solutions small quantities of pyrite, marcasite, native gold, and silver sulphosalts are deposited. The last moments of the mineralization process are characterized by the deposition of calcite, siderite and vivianite into the geodes. The presence of oxygen favours the apparition of $\mathrm{SO}_{4}{ }^{2-}$ anion, which contributes to the formation of baritine and gypsum. The mineralization process ends with the deposition of clay minerals at temperatures below $200^{\circ} \mathrm{C}$.

In hypergenic conditions, several secondary minerals are formed. The chalcopyrite can be substituted in the upper parts by small quantities of bornite. On a basis of manganese minerals (rhodochrozite and manganocalcite), and manganite is formed.

\section{Source of sulphur and metals}

The values $\delta^{34} \mathrm{~S}$ for a few sulphides from Herja are presented in Table 1. The value $\delta^{34} S$ close to zero would suggest a magmatic source, and the negative values, a sedimentary source (Pirajno, 1992).

The values obtained on sulphides from Herja vary within the limit for hydrothermal ore deposits, $\delta^{34} \mathrm{~S}= \pm 5 \%$. The strong negative values would suggest a biogene source for sulphur. The strong fragmentation of sulphur during the deposition could lead to values that show great differences for $\delta^{34} S$ even with 
negative values. This way, the first minerals have positive values for $\delta^{34} S$, and they can gradually become negative in the order of their crystallization sequence. The highly negative values could be due to the involving of sulphur from the surrounding sedimentary rocks into the final stage of the minerallogenetic process. If the hydrothermal ore deposits, genetically related to intrusions that could be the source of the solutions, lead to an unimportant isotopic fragmentation, then we can assume at Herja a contamination with biogenic sulphur.

Table 1

The values $\delta^{34} S^{*}$

\begin{tabular}{||l|l|l||}
\hline Sample no & Mineral & $\delta^{34} \mathrm{~S} \%_{0}$ \\
\hline \hline 1. Vein-90 $+250 \mathrm{~m}$ & Pyrite & $-8,01$ \\
\hline 2. Vein-90 oriz $+250 \mathrm{~m}$ & Galena & $-10,15$ \\
\hline 3. Vein-50 oriz $+250 \mathrm{~m}$ & Pyrite & $-8,23$ \\
\hline 4. Vein-50 oriz $+250 \mathrm{~m}$ & Galena & $-11,13$ \\
\hline 5. H-583 Fil. 30 & Pyrite & $-7,36$ \\
\hline 6. GV-101 Fil - 10 & Sphalerite & $-4,90$ \\
\hline 7. Vein 32 & Pirrhotite & $-5,10$ \\
\hline 8. Vein $-10 \mathrm{E}$ & Pyrite & $+2,56$ \\
\hline 9. Vein -1079 & Pyrite & $+3,08$ \\
\hline 10. Vein -100 & Galena & $-18,3$ \\
\hline
\end{tabular}

* 1-7 after Cook\&Damian (1997); 8-10 Analized at ITIM Cluj-Napoca

The results of the isotopic analyses on galena samples are present in Table 2. One can notice a greater percentage of radiogenic isotopes compared to the initial lead percentage. These results are similar to the data presented by Marcoux et al. (2002). These results emphasize the magmatic origin of lead in the hydrothermal ore fluids. The main source is the magma with a composition that does not change afterwards by magmatic differentiation. The assimilation of crust material with metal contents, during the ascension of magma towards the surface is also possible.

Table 2

Isotopic composition of lead*.

\begin{tabular}{||l|l|l|l|l||}
\hline \hline Samples & ${ }^{204} \mathrm{~Pb}$ & ${ }^{206} \mathrm{~Pb}$ & ${ }^{207} \mathrm{~Pb}$ & ${ }^{208} \mathrm{~Pb}$ \\
\hline \hline $\mathrm{H}-100$ & 1,51 & 25,64 & 21,36 & 51,49 \\
\hline$H-147$ & 1,41 & 25,42 & 21,23 & 51,94 \\
\hline$H-150$ & 1,26 & 25,40 & 21,10 & 52,24 \\
\hline$H-151$ & 1,48 & 25,10 & 21,20 & 52,22 \\
\hline
\end{tabular}

* analized at ITIM Cluj Napoca 
Genetic model of the ore deposit

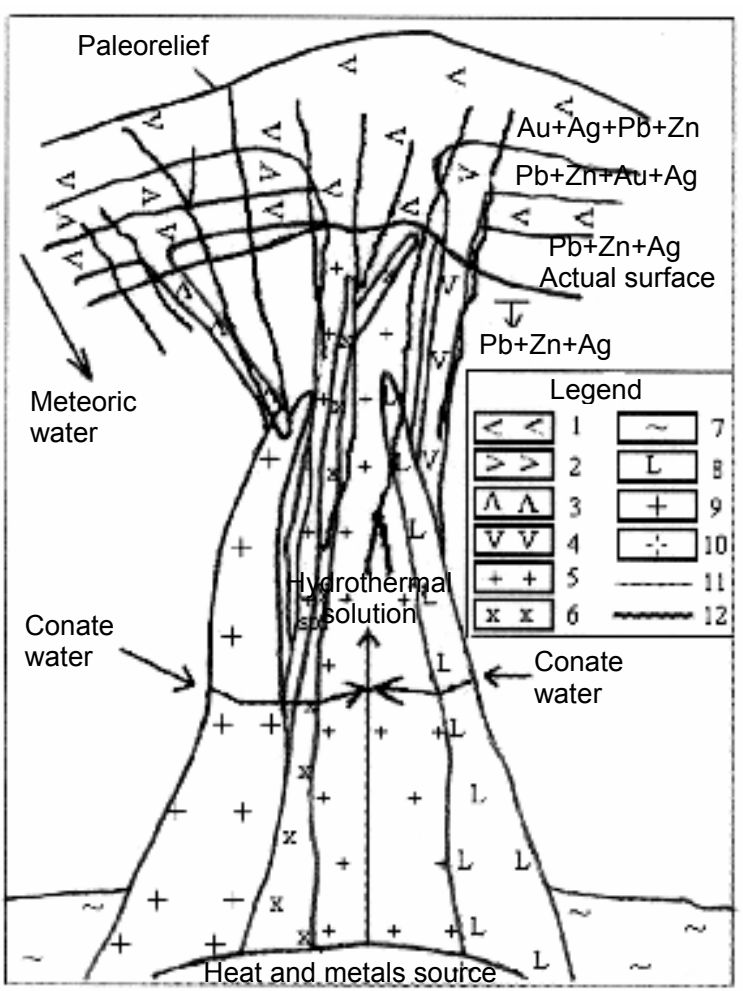

Fig. 6. Schematic model of the hydrothermal base metal ore deposit from Herja: 1 - pyroxene andesites; 2 - quartz andesites; 3 - quartz andesites 4 - pyroxene andesites 5 - porphyry quartz - microdiorites; 6 - porphyry microtonalites; 7- metamorphic rocks; 8 - porphyry quartz micromonzodiorites; 9 - porphyry microdiorites; 10 - pluton; 11 - limit; 12 - vein.
The Herja ore deposit is associated to a magmatic intrusion, made of a complex stock (Fig. 6). The association between the vein systems and the magmatic intrusions suggests a genetic relationship between the magma that generated the intrusions and the hydrothermal circulation. The structure from Herja favoured the penetration of the subvolcanic, which created, during its ascension, the system of tensional fractures localized both in sedimentary rocks and in magmatic rocks. The possibility that After Popescu (1986, 1994) and Borcoş et al. (1998) the fracture system may be controlled by the evolution of the crustal fracture DragoşVodă is not excluded because the ore deposit is situated in its nearby area.

The magmatic intrusions represent the apex part of a pluton (Fig. 6) developed in depth. The presence of a pluton in depth, which continues towards the surface with subvolcanic bodies was previously pointed out by Borcoş et al. (1998). This pluton was periodically activated having an important role in the metallogenetic initiation and distribution. This pluton represents the source of metals, heat and hidrothermal solutions that generated the mineralizations.

The hydrothermal alteration predominant in depth is the potassic one, made of potassic feldspar associated with small quantities of chlorite, sericite, quartz, magnetite, and biotite. Such potassic alterations have been described by Pirajno (1992) in association with the lower parts of the sulphides ore deposits. Outside the stock we can find a predominant intern alteration of propylitic type. The low temperature propylitic alteration (Pirajno, 1992) is specific to the upper external areas of the ore deposit, which are localized in the lava flows. 
The upper part (Fig. 6) is formed by a mineralization with sulphides of silver content and small quantities of gold, followed by an area with $\mathrm{Pb}+\mathrm{Zn}+\mathrm{Ag}$, and in depth, a mineralization of $\mathrm{Pb}+\mathrm{Zn}$ is predominant and it is extended to the level $-300 \mathrm{~m}$. In the northern veins, below level $+250 \mathrm{~m}$, an enriching in copper is noticed, which corresponds to a $\mathrm{Pb}+\mathrm{Zn}+\mathrm{Cu}$ type mineralization. Silitoe (1975) state that, in the magmatic arcs, the base-metal mineralizations of vein type, as the ones from Herja, develop in the upper parts of the stratovolcanos, and the ore deposits of porphyry copper type are situated at lower levels. Until now, in the Baia Mare district no porphyry copper system is known, but their presence related to the potassic altered subvolcanic rocks (Fig. 6) is not excluded, in the lower parts of the vein systems.

Many researchers (Taylor, 1979; Kejian et al., 1992) consider that the magma sets free a limited quantity of water into the hydrothermal solutions, which is insufficient for the developing of large dimension ore deposits. Generally, the andesitic magmas, as the ones from which the magmatic rocks from the Herja area were formed, can contain water in proportion of 3-20\%, depending on the pressure. As the magma rises to the upper part of the crust, it becomes volatile and the magmatic fluids are released.

To the forming of the mineralizing solutions an important contribution was brought by the great quantity of connate water. The intrusions from the Herja zone and their deeper correspondents are mostly localized in sedimentary rocks from which, because of the dehydratation processes they can take a great quantity of water. This water can mix with the water separated from the magma and enter the fractures around the intrusions.

Also, the magma rising towards the superficial parts can meet the meteoric water. This water is quickly absorbed by the magma heat and vaporized while the magma is heated and consolidated. The intense vaporization of meteoric water makes the exterior pressure rise, becoming higher than the internal pressure. Under these conditions the water from the nearby rocks is absorbed by the magma during its ascension and consolidation. The water takes a series of metal components from the magma which are afterwards deposited on the fractures where it circulates upwards. This process is highly obvious at Herja where the sedimentary rocks are dehydrated and thermic contact metamorphosed on a large area.

The studies made by Taylor (1979), Hayba et al. (1985) and Hedenquist (1995) based on oxygen and hydrogen isotopes proved that the hydrothermal solutions contain great quantities of surface water. Accorting to Hayba et al. (1985), Arribas (1995) and Hedenquist (1995), in the early stage the internal pressure of the magma and the solution separated from this, is bigger than the external pressure and the infiltration water can not enter the magma. This is why the early hydrothermal solutions contain great quantities of magmatic water.

The metal transfer from solution is as complex molecules, according to the data presented by Barnes (1967). The complex compounds are less stable in this type of solutions and that is why the transfer was probably carried out in 
solutions poor in sulphur. This type of transport would correspond to the observations made at Creede-Colorado by Hayba et al. (1985) for the sulphides mineralizations. Such ways of transport would have been possible for the Herja ore deposit where massive mineralizations rich in base metals exist.

During the first moments that followed the separation the solutions had a high salinity and a neutral or slightly acid $\mathrm{pH}$, because these ones are capable of increasing the solubility of the elements. At high temperatures and in the first stages of mineralization, the concentration of $\mathrm{H}_{2} \mathrm{~S}$ was low, favouring the deposition of pyrrhotite. Concomitantly, the great FeS activity makes possible the access of FeS in the sphalerite structure. The activity of sulphur continues to grow so that it will decrease again at low temperatures in the final stages of the mineralization. Once the salinity decreased towards the final stages of mineralization, the concentration of $\mathrm{CO}_{2}$ increased, favouring the growth of $\mathrm{CaCO}_{3}$ content. The presence of oxygen in the final stage facilitates the formation of anion $\mathrm{SO}_{4}{ }^{2-}$, because of the growing potential of oxido-reduction.

The main mechanism of deposition of the elements from the solutions is the filling of the holes, and only in the contact areas of the veins the metasomatism may be active. The reaction of the mineralizing solution with the host rocks, correlated with the decrease of temperature and pressure led to the reaching of the saturation limit for some compounds. The crystallization conditions of the sulphides, from the forming of pyrite to the deposition of galena, were kept constant.

Boiling is, for most ore deposits, one of the main factors which determine the deposition of sulphides in great quantities. According to Mitchel \& Leach (1991) the lack of brecious structures at Herja doesn't indicate the boiling. The association sphalerite-pyrrhotite was carried out at high temperatures, and the boiling could not start only at higher levels, mostly eroded now.

The native gold and the silver sulphosalts so frequent in the upper parts of the veins deposited after the solution mixture. The carbonates and especially the calcite deposited after the solution mixture under the conditions of $\mathrm{CO}_{2}$ saturation and a high fugacity of oxygen. The mixture of solutions and the presence of oxygen facilitates the deposition of baritine and gypsum in the presence of $\mathrm{SO}_{4}{ }^{2-}$ anion.

The Herja deposit was incluted by Borcoş et al. (1998) at the Cavnic epithermal base - metal and precious metal vein model. The Herja deposit is different from the Cavnic deposits and I consider that it represents a model by itself. The structural control, the association with magmatic intrusions, the mineralogical composition of the ores and the association with the hydrothermal alteration types are related with low sulphidation epithermal system mineralizations.

\section{REFERENCES}

Arnold R. G. 1962, Equilibrium relations of metal content of naturally occuring metal deficient, hexagonal pyrhotite by an X-ray spacing method. Am. Mineralogist, V 42, p. 105-111.

Arribas A. Jr. 1995, Characteristics of epithermal deposits, and their relatio to magmatic fluid, Mineral Resources, Geological Survey of Japan, $49 \mathrm{p}$. 
Balintoni I. 1997, Geotectonica terenurilor metamorfice din România, Ed. Carpatica, ClujNapoca, 176 p.

Barnes H. L. 1967, Geochemistry of hydrothermal ore deposits, Ed. Holt. Rinehart \& Winston, New York, 670 p.

Barton P.B.jr., Toulmin Pr. 1966, Phase relation involving sphalerite in the Fe-Zn-S system. Econ. Geol., V. 61, Nr. 5, p. 815-849.

Borcoş M., Lang B., Bostinescu S., Mîndroiu V., Volanschi E. 1973, Considerații privind activitatea metalogenetică asociată andezitelor piroxenice ponțiene din Munții Gutâi (zăcămintele Herja, Baia Sprie şi Şuior). St. teh. şi econ., seria I, nr. 9, p. 95-135, I.G.G. Bucureşti.

Borcoş M.,Vlad Ş. 1994, Plate tectonics and metallogeny in the east Carpathians and Apuseni M-ts. Baia Mare, 7-19 june, Field trip guide.

Borcoş M., Vlad Ş., Udubaşa Gh., Găbudeanu B. 1998, Qualitative and Quantitative Metallogenetic analysis of the Ore Genetic Units in Romania. Rom. J. of Mineral Deposits, 78, Special Issue, 7-107, I. Geol. Bucureşti.

Borman R. S. 1967, Subsolidus studies in the ZnS-FeS-FeS ${ }_{2}$ system. Econ. Geol. V. 62, p. 614-621.

Cook N. J., Damian Gh. 1997, New data on plumosite and other sulphosalt minerals from the Herja hydrothermal vein deposit, Baia Mare district, Romania. Geologica Carpathica, 48, 6, Bratislava, December, p. 387-399.

Damian Gh. 1986, Studiul mineralogic, geochimic şi genetic al zăcământului polimetalic de la Herja. Rez. Teză Doctorat, Univ. Bucureşti.

Edelstein O., Bernad A., Kovacs M., Crihan M., Pecskay Z. 1992, Preliminary date regarding the K-Ar ages of same eruptive rocks from Baia Mare Neogene volcanic zone. Rev. Roum. Geol., 36, p. 45-60, Bucureşti.

Ghißulescu I. P. 1935, Distribution de la mineralisation dans les gisments d'Age tertiare de Transylvanie (Reunion annuelle, Brad 2 oct. 1932). Bul. Societății Române de Geologie, vol. II, Bucureşti Ed. C. Românească.

Giuşcă D., Borcoş M., Lang B., Stan N. 1973, Neogene Volcanism and Metallogenesis in the Gutâi Mountains. Guide Excursion 1AB, I.G.G. Bucureşti.

Hayba D.O., Bethke Ph.M., Heald Pamela, Foley K. N. 1985, Geologic, Mineralogic and Geochemical Characteristics of Volcanic-Hosted Epitermal Precious-Metal Deposits Systems. Society of Econ. Geologists, Univ. of Texas, p. 129-231.

Hedenquist J.W. 1995, Origin of and exploration for epithermal gold deposits. Mineral Resources Departament, Geological Survey of Japan, p. 120.

Hutchinson N. M., Scott S. D. 1981, Sphalerite geobarometry in the Cu-Fe-Zn-S system. Econ. Geol. V. 76, p. 143-156.

lanovici V., Giuşcă D., Manilici V., Gherasi N., Jude R., Gherghiță I., Dimitrescu R. 1961, Privire generală asupra geologiei regiunii Baia Mare. Congres. Asoc. geol. Carp. Balc., al V-lea congres, Ghidul excursiilor, Bucureşti.

Iştvan D., Edelstein O., Bernad A., Stan D., Kovacs M. 1986, Raport asupra prospecțiunilor geologice executate pentru mineralizații neferoase în perimetrul Tăuții de SusChiuzbaia-Baia Sprie. Arhiva IPEG S.A. Baia Mare.

Jude R. 1960, Raport geologic asupra cercetărilor din regiunea Baia Mare (Mina Herja). Arhiva I. G., Bucureşti.

Kejian Ji, Xuchan Wu, Zhang Gouting 1992, Ore source, water source and heat source for hydrothermal deposits and regularity of their distribution. Geological Publishing House, Beinjing, China, p. 187. 
Kovacs M., Edelstein O., Iştvan D., Grabari G., Stoian M., Popescu Gh. 1992, Distribution of R.E.E., K, Rb, $\mathrm{Sr}$, and of the ${ }^{87} \mathrm{Sr} /{ }^{86} \mathrm{Sr}$ rations in the neogen andesits of the IgnişVăratec Mountains (Gutâi). Rom. J. Petrology, 75, p. 145-159.

Manilici V., Dumitrescu A. 1981, Temperaturile de formare ale minereurilor polimetalice din zona Baia Mare. St. cerc., geol., geofiz., geogr., Seria Geologie, t 26, nr. 1.

Marcoux E., Grancea L., Lupulescu M., Milési J. P. 2002, Lead isotope signatures of epithermal and porphyry - type ore deposits from the Romanian Carpathian Mountains, Mineralium Deposita 37 (2002), p. 173 - 184.

Măldărescu I. 1977, Une possibilité d'estimer la profondeur de formation des gisments hydrothermaux filoniens, An. Univ. Bucureşti, XXVI.

Mitchel A. H. G., Leach T. M. 1991, Epithermal Gold in the Philippines Island Arc Metallogenesis, Geothermal Systems and Geology, Academic press, London, San Diego, New York, Boston, 457 p.

Ohmato H., Rye R.O. 1979, Isotopes of Sulfur and Carbon, in Geochemistry of hydrothermal ore deposits, Secon Edition, Edited by H. L., Barnes, John Wiley and sons, New York, Toronto.

Petrulian N. 1934, Étude chalcografhique du gisments de plomb et de zinc de Herja (Trasilvanie-Roumanie). An. Inst. Geol. Roum., Vol. XVI, p. 539-574, Bucureşti.

Pirajno F. 1992, Hydrothermal mineral deposit: Principles and Fundamental Concepts for the Exploration Gedologis, Springer-Verlag Berlin-Heidelberg-New York-London-ParisTokyo-Hong Kong-Barcelona-Budapest, 709 p.

Polonic P., Polonic G. 1962, Contribuțiuni la studiul geologic al regiunii Chiuzbaia (Baia Mare). D de S., Inst.Geol. Bucureşti, XLVII (1959-1960), p. 253-261.

Pomârleanu V. 1971, Geotermometria şi aplicarea ei la unele minerale din România. Ed. Academiei Române Bucureşti, 158 p.

Popescu C. Gh. 1986, Metalogenie aplicată şi prognoză geologică. Partea a II-a, Ed. Univ. Bucureşti.

Popescu C. Gh. 1994, A Geodynamic Model Regarding The Neogene Volcanism And The Associated Metallogenesis In Baia Mare Metallogenetic District (The East Carpathians). An. Univ. Bucureşti, XLIII, p. 19-26.

Rădulescu D., Săndulescu M. 1973, The Plate Tectonics Concept and Geological Structure of the Carpathians. Tectonophysics, 19, 3, p. 155-161, Amsterdam.

Scott S. D. 1973, Experimental calibration of the sphalerite geobarometer. Econ. Geol. 68, p. $466-474$.

Scott S. D., Barnes H. L. 1971, Sphalerite Geothermometry and Geobarometry. Econ. Geol., 66, p. 653-669.

Sillitoe R. H. 1975, Lead-silver manganese and native sulphur mineralization within a stratovolcano, El Queva, Northwest Argentina. Econ. Geol. 70, 1190-1201.

Stanciu Costantina 1973, Procese de transformare hidrotermală în zăcămintele Herja şi Baia Sprie-Munții Gutâi. St. tehn. econ., seria I, nr. 9, p. 73-94, Inst. Geol. Bucureşti.

Taylor H. P. Jr 1979, Oxigen and hidrogen isotope relationships in hydrotermal mineral deposits, in Barnes H. L., Geochemistry of hydrotermal ore deposits. 2nd Edition, John Wiley and Sons New York.

Udubaşa G., Zămîrcă A., Andar P., Andar A. 1985, Caractere tipomorfe ale unor mineralizaßii asociate structurilor vulcanice din România. D. de S., Inst. de Geol. şi Geofiz. Bucureşti, LXIX (1982), nr. 2, p. 89-114. 